\title{
Tıp Fakültesi Öğrencilerinin Bilişsel Esneklik Düzeyleri, Öğrenme Yaklaşımları ve Kullandıkları Öğrenme Stratejileri (Çanakkale Örneği)
}

\section{Cognitive Flexibilty Levels, Learning Approaches and Learning Strategies of the Medical Students (The Example of Çanakkale)}

\author{
Çetin Toraman (ORCID ID: 0000-0001-5319-07319) \\ Ayşen Melek Aytuğ Koşan (ORCID ID: 0000-0001-5298-2032) \\ Mustafa Onur Yurdal (ORCID ID: 0000-0002-9632-7192) \\ Çanakkale Onsekiz Mart Üniversitesi, Tıp Fakültesi, Çanakkale \\ Sorumlu Yazar: \\ Dr. Öğr. Üyesi Çetin Toraman \\ Çanakkale Onsekiz Mart Üniversitesi, Tıp Fakültesi, Tıp Eğitimi Anabilim Dalı \\ Terzioğlu Yerleşkesi Merkez, Çanakkale E-posta: toramanacademic@gmail.com
}

Anahtar Sözcükler:

Bilişsel Esneklik, Öğrenme

Yaklaşımı, Öğrenme

Stratejisi, Tıp Eğitimi

Keywords:

Cognitive Flexibility,

Learning Approach,

Learning Strategy, Medical

Education

Gönderilme Tarihi

Submitted:08.07.2019

Kabul Tarihi

Accepted: 28.12.2019

\section{ÖZET:}

Amaç: Bu araştırmanın amacı, üniversite öğrencilerinin bilişsel esneklik düzeyleri, öğrenme yaklaşımları ile kullandıkları öğrenme stratejilerini belirlemek, bunlar arasındaki ilişkileri incelemek; öğrencilerin öğrenme, ögretme ve sınavlara yönelik görüşlerini belirlemektir.

Gereç ve Yöntem: Araştırmada açımlayıcı desen karma araştırma yöntemi kullanılmıştır. Araştırmanın nicel kısmında öğrencilerin bilişsel esneklik düzeyleri, öğrenme yaklaşımları ve kullandıkları öğrenme stratejileri incelenmiş ve aralarındaki ilişkiler belirlenmiştir. Araştırmanın nitel kısmında bilişsel esneklik, öğrenme yaklaşımları ve öğrenme stratejileri ölçeğinden öğrencilerin elde ettikleri puanlar göz önünde bulundurularak, bu ölçeklerden yüksek ve düşük puan alan her dönemden iki öğrenci olmak üzere toplam on iki öğrenci odak grup olarak belirlenmiş ve bu öğrencilerle görüşme gerçekleştirilmiştir. Araştırmanın nicel kısmında tıp fakültesi dönem I'den dönem VI'ya 626 öğrenci, nitel kısımda ise odak grupta yer alan 12 öğrenci araştırma grubunu oluşturmuştur.

Künye: Toraman Ç, Aytuğ Koşan AM, Yurdal MO. Tip Fakültesi Öğrencilerinin Bilişsel Esneklik Düzeyleri, Öğrenme Yaklaşımları ve Kullandıkları Öğrenme Stratejileri (Çanakkale Örneği). Tıp Ĕ̆itimi Dünyast. 2020;19(57):76-97 
Veriler, Martin ve Rubin tarafından geliştirilmiş Altunkol tarafindan Türkçeye uyarlanmış olan "Bilişsel Esneklik Ölçeği”"; Batı, Tetik ve Gürpınar tarafından Türkçeye uyarlanmış olan “Öğrenme Yaklaşımları Ölçeği”; Çelikkaya tarafından geliştirilmiştir öğrenme stratejileri ölçeğiyle elde edilmiştir.

Bulgular: Araştırma sonucunda tıp fakültesi öğrencilerinin bilişsel esneklik düzeyinin yüksek olduğu, derin ve yüzeysel öğrenme yaklaşımına sahip olmakla birlikte derin öğrenme yaklaşımlarının yüzeysel öğrenme yaklaşımlarından bir miktar yüksek olduğu, sosyo-duyuşsal, anlamlandırma, tekrar ve dikkat öğrenme stratejilerinin her birinden yararlandıkları belirlenmiştir. Erkeklerin yüzeysel öğrenme eğilimi kadınlardan yüksektir. Kadınlar dikkat öğrenme stratejisini erkeklerden daha çok kullanmaktadır. Çalışmada yer alan öğrenciler, sınavların kendilerinin öğrenme düzeylerini ölçmediğini, sınavların onları "bilgiyi ezberlemeye" yönlendirdiğini belirtmiştir.

Sonuçlar: Derin öğrenme yaklaşımı ile yüzeysel öğrenme yaklaşımının bir arada yüksek miktarda kullanılması bir çelişki gibi görünse de odak grup görüşmeleri göstermiştir ki; eğitim sistemi öğrencilere bazı mesajlar vermektedir: "Derin öğrenmeye çalışırsan sınıfı geçebileceğin garanti değil, ancak gereken bilgileri ezberlersen durum net: Başarı!’. Bilişsel esneklik arttıkça sosyo-duyuşsal öğrenme stratejisi kullanımı da artmaktadır. Derin öğrenme yaklaşımı arttıkça sosyo-duyuşsal öğrenme stratejisi, anlamlandırma öğrenme stratejisi ve tekrar öğrenme stratejisi kullanımı artmaktadır.

\section{ABSTRACT:}

Purpose: This study aims to investigate university students' cognitive flexibility level, learning approaches and strategies they use as well as the relations between these approaches and strategies and students' opinions on learning, teaching and exams.

Instrument and Method: In this study, exploratory design mixed research method was applied. In the quantitative part of the study, students' cognitive flexibility levels, learning approaches, and strategies they use were investigated and the relations among them were determined. In the qualitative part of the study, 12 student centered interviews, of both semesters, were conducted with those who had high and low grades from cognitive flexibility, learning approaches and learning strategies scale. In the quantitative part of the study, 626 students of medical school from I. year to the VI and in the qualitative part, the 12 students who were in the focus group formed the study group. Data were obtained through "Cognitive Flexibility Scale" developed by Martin and Rubin and adapted into Turkish by Altunkol; "Learning Approaches Scale" adapted into Turkish by Batl, Tetik and Gurpinar and "Learning Strategies Scale" developed by Çetinkaya.

Findings: In the study it was revealed that medical faculty students' cognitive flexibility level was high; students had both deep and surface learning approaches while deep learning approaches were higher than surface ones to a certain extent, students benefited from each of socio-emotional, sense-making, repetition and attention learning strategies. Male students, surface learning tendency is higher than that of the female. The female students use attention learning strategy more than the male ones do. The students that took part in the study claimed that the examinations did not measure their learning degree and forced them to towards "memorizing information".

Results: While using deep learning approach and surface learning approach at a high 
quantity may seem as a contradiction, focus group interviews have shown that education system gives some messages to students: "If you study deeply, it is not certain to pass; but if you memorize, it is clear: Success!'. When cognitive flexibility increases, the usage of socioemotional learning strategy also increases. When deep learning approach increases, the use of socio-emotional learning strategy, sense-making learning strategy and repetition learning strategy increases.

\section{GİRIŞ}

Bilişsel esneklik bireyin, farklı durumlarda seçenekleri ve alternatifleri olduğuna dair farkındalık durumunu (1) ifade etmekle birlikte, değişen ortam koşullarına göre algısını değiştirebilme yeteneğine de işaret etmektedir (2). Bilişsel esneklik düzeyi yüksek bireyler, alternatifler yaratabilir ve zor durumlarla kolay şekilde başa çıkabilir (3), karmaşık ve hızlı değişen dünyanın parçası olma yolunda firsatları kolaylıkla kullanabilir, değişimle baş edebilirler $(4,5)$, birden fazla bilgiyi aynı anda işler, çoklu fikir üretir, gerektiğinde planları hızlı şekilde değiştirebilirler $(6,7)$. Bir duruma uyum sağlamada çoklu strateji üretme ve bunlar arasında kolay geçişler yapabilme yeteneğidir (8). Bilişsel esneklik üç öğeyi içerir. Bunlar (1); alternatif yolların ve seçeneklerin farkında olma, esnek olmaya ve uyum sağlamaya istekli olma, öz yeterlik ya da esnek olma yeteneğine sahip olma inancıdır. Bilişsel esneklik, deneyime dayalı yeni ve beklenmedik çevresel değişikliklere uyum sağlamayı içerir. $\mathrm{Bu}$ nedenle bilişsel esnekliğin öğrenilebilir bir özellik olduğu söylenebilir.

Literatür incelendiğinde, bilişsel esnekliğin stres (9); sosyal yetkinlik beklentisi, otoriter anne baba tutumu ve problem çözme becerisi (10); öfke (11); bağlanma stilleri, akılcı olmayan inançlar ve psikolojik belirtiler (12); öz duyarlık (13); değişimlere açık olma ve akademik performans (14); aneroksia (15) ile ilişkili olduğu görülmektedir. Bazı bulgular erkeklerin bilişsel esneklik düzeyinin kızlardan yüksek olduğunu gösterirken (9), bazılarında cinsiyete göre farklılık olmadığı görülmektedir (11). Ayrıca bilişsel esnekliğin, kavgacı olmama, toleranslı olma ve sözel saldırganlık (1); sosyal yetkinlik inancı ve problem çözme becerisi (10); depresyon (16); bilişsel yetenekler $(17,18)$; dil (19); aritmetik beceriler (20), problem çözme odaklı stresle baş etme (2) ve işbirliğine dayalı karar verme ile ilişkili olduğu saptanmıştır. Bu araştırmada ise, üniversite öğrencilerinin bilişsel esneklik düzeylerinin öğrenme yaklaşımları ve kullandıkları öğrenme stratejileriyle ilişkisi araştırılmıştır.

Araştırmada bilişsel esneklik ve öğrenme stratejileri ile ilişkili olabileceği düşünülen bir diğer değişken de öğrenme yaklaşımlarıdır. Derin ve yüzeysel öğrenme yaklaşımının birer terim olarak kullanımı çok eski yıllara dayanmamaktadır 1970-80'li yıllarda ortaya atılmış kavramlardır (21). Son yıllarda öğrenme yaklaşımları özellikle yüksek öğretimde, bazı öğrencilerin diğer öğrencilere kıyasla neden daha başarılı olduklarını açıklamada evrensel bir tema haline gelmiştir (22). Yüzeysel öğrenme yaklaşımı, bireylerin az çabayla sınavı geçecek kadar çalışmayı gerektiren, bu doğruda yapılandırılmış ortamları tercih etme ile karakterizedir. Dolayısı ile düşük nitelikli öğrenme sonuçlarına yol açan bir yaklaşımdır. Derin öğrenme yaklaşımı konuyu, materyali anlamayı, eski bilinenlerle yeni öğrenilenlerin entegrasyonunu gerektirmektedir (23).

Biggs (24), derin ve yüzeysel öğrenme yaklaşımlarına ait başlıca özellikler şöyle sıralamıştır. Derin öğrenme yaklaşımı; öğrenme öznesine ilgi duyma ve bu görevi 
gerçekleştirmekten zevk alma, öğrenme öznesinin özündeki anlamı arama (örneğin, bir deneme yazısı incelenirken yazarın niyetini de sorgulama gibi), öğrenme öznesini içselleştirerek kendi deneyimi ve gerçek dünya için anlamlı kılma, öğrenme öznesinin parça veya bölümlerini birleştirerek bir bütüne ulaşma ve bu bütünle parçalar, ayrıca önceki öğrenmelerle ilişki kurma, öğrenme öznesini kuramsallaştırmaya çalışma, hipotezler oluşturma ile karakterizedir. Yüzeysel öğrenme yaklaşımı; öğrenme öznesini gerekli başka bir hedefe ulaşmak için bir aşama olarak görme, öğrenme öznesinin kişisel ve anlamsal yönlerinden kaçınma, görevin alacağı zaman konusunda kayg1 duyma, öğrenme öznesinin parçalarını veya bölümlerini birbirlerinin ilişkileri dışında ayrı ayrı olarak görme, öğrenme öznesini zihninde şekillendirmeye çalışırken görevin yüzeysel parçalarını ezberlemeye odaklanma (örneğin, kullanılan; kelimeler, örnekler, şemalar veya anımsatıcılar gibi) ile karakterizedir.

Öğrenme sürecini etkileyen ve bu araştırmanın da değişkenlerinden biri olan bir diğer etmen öğrenme stratejileridir. Açıkgöz'e (25) göre strateji bir şeyi elde etmek için izlenen yol ya da bir amaca ulaşmak için geliştirilen bir planın uygulanması olarak tanımlanmaktadır.

Öğrenme stratejileri; öğrencinin öğrenme sürecinde bilgiyi nasıl seçeceği, seçtiği bilgiyi nasıl edineceği, edindiği bilgiyi nasıl oluşturacağı ve bu bilgileri birleştirerek yeni bilgi oluşturmada kendilerine yardımcı olan belirli strateji ve yöntemler olabildiği gibi (26), belleğe yerleştirme, geri getirme gibi bilişsel stratejilerle birlikte öğrencinin öğrenmesini etkileyen ve ögrrenci tarafından kullanılan davranış ve düşünme süreçleri olarak da belirtilmiştir (27). Aynı zamanda stratejiler, psikolojide kodlama ve geri çağırma olarak tanımlanmaktadır. Bir strateji, beyinde var olan bilgiler ile çevreden elde edilen bilgilerin birleştirilmesinin veya düzenlenmesinin bir yoludur (28). Ayrıca öğrenme stratejileri; öğrencinin kolay ve kalıcı öğrenmesini sağlama, bilinçli öğrenme, verimliliğin artması, öğrenciye bağımsız öğrenebilme yeteneği kazandırma gibi başka işlevleri de yerine getirmektedir (29).

Literatürde bilişsel esneklik, yüzeysel öğrenme yaklaşımı, derin öğrenme yaklaşımı ve öğrenme stratejileri arasındaki ilişkiyi inceleyen herhangi bir araştırmaya rastlanmamıştır. $\mathrm{Bu}$ durum araştırmanın motivasyonunu sağlayan itici güç olmuştur. Bu bağlamda araştırmanın amacı;

a) Çanakkale Onsekiz Mart Üniversitesi, Tıp Fakültesinde öğrenim gören öğrencilerin bilişsel esneklik düzeyleri, öğrenme yaklaşımları ile kullandıkları öğrenme stratejilerini belirlemek,

b) Çeşitli değişkenler bakımından (ders dış1 kitaplar okuma, anne eğitim düzeyi, baba eğitim düzeyi) bilişsel esneklik düzeyi, öğrenme yaklaşımları ve kullanılan öğrenme stratejileri arasında anlamlı farklılıklar olup olmadığını belirlemek,

c) Bilişsel esneklik düzeyi, öğrenme yaklaşımları ve kullanılan öğrenme stratejileri arasındaki ilişkileri incelemek,

d) Bilişsel esneklik, öğrenme yaklaşımları ve öğrenme stratejilerinin öğrencilerin öğrenme, öğretme ve sınavlara yönelik görüşlerine nasıl bir yön verdiğinin incelenmesidir.

\section{GEREÇ VE YÖNTEM}

Araştırmada nicel ve nitel araştırma ve çözümleme tekniklerine başvurulmuştur. Araştırmada önce nicel verilerin daha sonra nitel verilerin toplanması ve çözümlenmesi biçiminde 
tasarlanan açımlayıcı desen kullanılmıştır.

Araştırmanın nicel kısmında öğrencilerin bilişsel esneklik düzeyleri, öğrenme yaklaşımları ve kullandıkları öğrenme stratejileri incelenmiş ve betimlenmiştir. Araştırma bu yönüyle nicel tanılayıcı türde bir araştırmadır. Diğer yandan araştırmanın nicel kısmında öğrencilerin bilişsel esneklik düzeyi, öğrenme yaklaşımı ve kullandıkları öğrenme stratejileri arasındaki ilişkiler de incelenmiştir. $\mathrm{Bu}$ yönüyle de araştırma ilişkisel karşılaştırma türünde bir araştırmadır.

Araştırmanın nitel kısmında bilişsel esneklik, öğrenme yaklaşımları ve öğrenme stratejileri ölçeğinden öğrencilerin elde ettikleri puanlar göz önünde bulundurularak, bu ölçeklerden yüksek ve düşük puan alan her dönemden iki öğrenci olmak üzere toplam 12 öğrenci belirlenmiştir. $\mathrm{Bu}$ öğrencilerle odak grup görüşmesi yapılmıştır.

\section{a. Araştırma Grubu}

Araştırma Çanakkale Üniversitesi Tip Fakültesinde yürütülmüştür. Araştırma Fakülte Dekanlığının 14/05/2019 tarih ve 1900070456 sayılı izni alınarak gerçekleştirilmiştir. Tüm tıp fakültesi öğrencileriyle gönüllülük temelinde yürütülen araştırmanın nicel bölümüne öğrencilerin büyük bir bölümü katılmıştır.

Nitel veriler için amaçlı örnekleme yöntemlerinden ölçüt örnekleme yöntemi kullanılmıştır. Bu araştırmada odak gruba alınma ölçütü, uygulanan ölçeklerden yüksek ve düşük puanlar elde etme, farklı dönemlerde öğrenim görme ve odak grup görüşmesi için gönüllü olmaktır. Bu yolla odak grupta 12 öğrenci yer almıştır. Araştırmaya katılan öğrencilerin sahip olduğu özellikler Tablo 1'de verilmiştir (Tablo 1).

Araştırma nicel verileri Mayıs 2019 içerisinde, nitel veriler ise Haziran 2019 içerisinde elde edilerek ardışık strateji izlenmiştir.

\section{b. Veri Toplama Araçları}

$\mathrm{Bu}$ araştırmada öğrencilerden üç farklı değişkene ait veri elde edilmiştir. Bunlar; bilişsel esneklik düzeyi, öğrenme yaklaşımları ve kullanılan öğrenme stratejileridir. Araştırmada Martin ve Rubin (9) tarafından geliştirilmiş ve üniversite öğrencileri için Altunkol (9) tarafından Türkçeye uyarlanmış olan Bilişsel Esneklik Ölçeği ile öğrencilerin bilişsel esneklik düzeyleri belirlenmiştir. Ölçek 12 maddeden oluşmaktadır. Likert tipi ve 6 dereceli olarak geliştirilmiştir. Ölçekten alınabilecek en düşük puan 12, en yüksek puan ise 72 ' dir. Yüksek puan almak yüksek bilişsel esnekliği göstermektedir. Öğrencilerin öğrenme yaklaşımları Biggs tarafından geliştirilmiş, Batı, Tetik ve Gürpınar (22) tarafından Türkçeye uyarlanmış olan Öğrenme Yaklaşımları Ölçeği ile belirlenmiştir. Ölçek iki alt boyuttan oluşmaktadır. Derin öğrenme yaklaşımı 10 maddeden oluşmaktadır ve ölçekten alınabilecek en düşük puan 10 , en yüksek puan 50'dir. Yüzeysel öğrenme yaklaşımı 10 maddeden oluşmaktadır ve ölçekten alınabilecek en düşük puan 10, en yüksek puan 50'dir.

Öğrencilerin kullandıkları öğrenme stratejileri ölçeği Çelikkaya (30) tarafından geliştirilmiştir. Ölçek Likert tipi bir ölçektir. Dört alt ölçeği bulunmaktadır. Sosyo-duyuşsal öğrenme stratejisi boyutunda 18 madde yer almaktadır ve alınabilecek en yüksek puan 90'dır. Anlamlandırma öğrenme stratejisi boyutunda 13 madde yer almaktadır ve alınabilecek en yüksek puan 65 'tir. Tekrar öğrenme stratejisinde 5 madde yer almaktadır ve alınabilecek en yüksek puan $25^{\prime}$ 'tir. Son olarak dikkat öğrenme stratejisi boyutunda 4 madde yer almaktadır ve alınabilecek en yüksek puan 20'dir.

Araştırmada odak gruba alınan öğrencilerle yarı 
yapılandırılmış görüşme formu ile veri elde edilmiştir. $\mathrm{Bu}$ form araştırmacılar tarafından oluşturulmuştur. Forma ilişkin tıp eğitiminden iki, eğitim bilimlerinden iki ve nitel araştırma deneyimi olan bir akademisyenden alınan görüşler doğrultusunda görüşme formuna son hali verilmiştir. Görüşme formundaki sorular öğrenme, öğretme ortamı ve uygulanan sınavlar (ölçme kültürü) aracılığı ile öğrencilere bilişsel esneklik, öğrenme yaklaşımı ve öğrenme stratejisi kullanımına yönelik verilen örtük mesajları ve anlamlandırmaları ortaya çıkarmaya yöneliktir.

\section{c. Verilerin Analizi}

Araştırmada elde edilen nicel veriler IBMSPSS 23'e ve STATA 14'e aktarilarak analiz edilmiştir. İki ayrı programın kullanılma nedeni; çok değişkenli regresyon analizinin IBMSPSS'te bulunmamasıdır. Nitel verilerin analizi manuel olarak gerçekleştirilmiştir.

Veri analizinde; aritmetik ortalama, mod, medyan, standart sapma gibi betimleyici analizler; cinsiyet, sınıf, anne eğitimi vb. değişkenlere göre karşılaştırma testleri; bilişsel esneklik düzeyi, öğrenme yaklaşımı, kullanılan öğrenme stratejisi arasında ilişki ve regresyon analizleri yapılması gerekmektedir. Karşılaştırma, ilişki ve regresyon analizlerinin parametrik ve nonparametrik olanları bulunmaktadır. Parametrik istatistik analizler belli varsayımları gerektirmektedir. Bunlardan en önemlisi karşılaştırma, ilişki, regresyon analizi yapılacak değişkenlere (bilişsel esneklik, öğrenme yaklaşımı, öğrenme stratejisi) ait verilerin normal dağılım göstermesidir (31). $\mathrm{Bu}$ nedenle Bilişsel Esneklik Ölçeği toplam puanları, Öğrenme Yaklaşımları Ölçeği iki alt boyutuna ait verilerin toplam puanları, Öğrenme Stratejileri Ölçeği dört alt boyutuna ait toplam puanlara "Kolmogorov Smirnov Normal
Dağılım Testi" (31, 32, 33, 34) uygulanmıştır. Elde edilen test sonucunda anlamlılık değeri verilerin normal dağılıma uymadığını $(p<.05)$ göstermiştir.

Normalliği test eden testler aşırı duyarlı testlerdir (35). Ayrıca birçok araştırmada (özellikle sosyal bilimlerde) bağımlı değişkenlere ilişsin ölçümler normal dağılım göstermemektedir (36). Merkezi Limit Teoremi, eğer örneklem yeteri kadar büyükse $(n=30+)$, değişkenlerin dağılımına bakılmaksızın ortalamaların örnekleme dağılımının normal dağılacağını, normal dağılım ihlalinin büyük bir soruna neden olmayacağı öne sürmektedir $(35,36,37$, 38). Büyük örneklemlerde çarpıklık normalden önemli derecede sapmamaktadır. 100'den fazla örneklem büyüklüğünde pozitif basıklık, 200'den büyük örneklemde negatif basıklık kaybolmaya başlamaktadır (35). Bu bilgiler doğrultusunda analizlerin parametrik istatistiki tekniklerle yapılmasına karar verilmiştir.

Odak grup görüşmesinde öğrencilere yönlendirilen açık uçlu sorular ile elde edilen verilerüzerinde içerik analizi gerçekleştirilmiştir.

\section{BULGULAR}

Araştırmanın amacı doğrultusunda bilişsel esneklik ölçeği, öğrenme yaklaşımları ölçeği ve öğrenme stratejileri ölçeği aracılığıyla elde edilen veriler doğrultusunda tıp fakültesi öğrencilerinin bilişsel esneklik düzeyleri, öğrenme yaklaşımları ve kullandıkları öğrenme stratejileri incelenmiştir. Tablo 2'de bu değişkenlere ait betimsel istatistiklere yer verilmiştir (Tablo 2).

Bilişsel esneklik ölçeğinde yer alan soru sayısı gereği alınabilecek en yüksek puan 72 'dir. Öğrencilerin aldığı ortalama puan 45,94 olarak gerçekleşmiştir. Mod, yani en çok tekrar eden puan 48 olarak gerçekleşmiştir. Öğrencilerin ortalama ve mod değerleri ölçekten alınabilecek 
en fazla puanın yarısı olan 36'yı geçmiştir. $\mathrm{Bu}$ durumda öğrencilerin bilişsel esneklik düzeylerinin yüksek olduğu yorumu yapılabilir. Öğrenme yaklaşımları ölçeğinin değerlendirmesinde; Derin öğrenme alt ölçeğinde yer alan soru sayısı gereği alınabilecek en yüksek puan 50'dir. Öğrencilerin aldığ 1 ortalama puan 31,37 olarak gerçekleşmiştir. Mod, yani en çok tekrar eden puan 30 olarak gerçekleşmiştir. Öğrencilerin ortalama ve mod değerleri bu alt ölçekten alınabilecek en fazla puanın yarısı olan 25'i geçmiştir. Bu durumda öğrencilerin derin öğrenme yaklaşımlarının yüksek olduğu yorumu yapılabilir.

Yüzeysel öğrenme alt ölçeğinde yer alan soru sayısı gereği alınabilecek en yüksek puan 50'dir. Öğrencilerin aldığı ortalama puan 29,45 olarak gerçekleşmiştir. Mod, yani en çok tekrar eden puan 30 olarak gerçekleşmiştir. Öğrencilerin ortalama ve mod değerleri bu alt ölçekten alınabilecek en fazla puanın yarısı olan 25'i geçmiştir. $\mathrm{Bu}$ durumda öğrencilerin yüzeysel öğrenme yaklaşımlarının yüksek olduğu yorumu yapılabilir. Derin öğrenme yaklaşımı ile yüzeysel öğrenme yaklaşımı puanları birbirlerine oldukça yakın gerçekleşmiştir. Derin öğrenme yaklaşımı çok küçük bir miktar da olsa daha fazladır.

Sosyoduygusal öğrenme stratejisi alt ölçeğinde yer alan soru sayısı gereği alınabilecek en yüksek puan 90'dır. Öğrencilerin aldığ1 ortalama puan 59,60 olarak gerçekleşmiştir. Mod, yani en çok tekrar eden puan 54 olarak gerçekleşmiştir. Öğrencilerin ortalama ve mod değerleri bu alt ölçekten alınabilecek en fazla puanın yarısı olan 45'i geçmiştir. Bu durumda öğrencilerin sosyoduygusal öğrenme stratejisini tercih ettikleri yorumu yapılabilir.

Anlamlandırma öğrenme stratejisi alt ölçeğinde yer alan soru sayısı gereği alınabilecek en yüksek puan 65 'tir. Öğrencilerin aldığı ortalama puan 43,91 olarak gerçekleşmiştir. Mod, yani en çok tekrar eden puan 39 olarak gerçekleşmiştir. Öğrencilerin ortalama ve mod değerleri bu alt ölçekten alınabilecek en fazla puanın yarısı olan 32,5'i geçmiştir. Bu durumda öğrencilerin anlamlandırma öğrenme stratejisini tercih ettikleri yorumu yapılabilir.

Tekrar öğrenme stratejisi alt ölçeğinde yer alan soru sayısı gereği alınabilecek en yüksek puan 25 'tir. Öğrencilerin aldığ 1 ortalama puan 16,73 olarak gerçekleşmiştir. Mod, yani en çok tekrar eden puan 15 olarak gerçekleşmiştir. Öğrencilerin ortalama ve mod değerleri bu alt ölçekten alınabilecek en fazla puanın yarısı olan 12,5'i geçmiştir. Bu durumda öğrencilerin tekrar öğrenme stratejisini seçtikleri yorumu yapilabilir.

Dikkat öğrenme stratejisi alt ölçeğinde yer alan soru sayısı gereği alınabilecek en yüksek puan 20'dir. Öğrencilerin aldığ 14,54 olarak gerçekleşmiştir. Mod, yani en çok tekrar eden puan 12 olarak gerçekleşmiştir. Öğrencilerin ortalama ve mod değerleri bu alt ölçekten alınabilecek en fazla puanın yarısı olan 10'u geçmiştir. Bu durumda öğrencilerin dikkat öğrenme stratejisini tercih ettikleri yorumu yapilabilir.

$\mathrm{Bu}$ sonuçlar birlikte yorumlandığında; öğrencilerin bilişsel esneklik düzeyinin yüksek olduğu, derin öğrenme yaklaşımını yüzeysel öğrenme yaklaşımından biraz daha çok tercih ettiklerini, öğrenmek için onları amaca götürecek tüm öğrenme stratejilerini (sosyoduygusal, anlamlandırma, tekrar ve dikkat) kullandıkları söylenebilir.

\section{a. Farklı Değişkenlere Göre Bilişsel Esneklik, Öğrenme Yaklaşımları ve Öğrenme Stratejilerinin Karşılaştırılması}

Cinsiyet, Dönem, Bilişsel Esneklik, Öğrenme Yaklaşımı ve Öğrenme Stratejisi 
Araştırmada öğrencilerin bilişsel esneklik düzeyi, öğrenme yaklaşımı ve kullandıkları öğrenme stratejisi üzerinde öğrencilerin cinsiyeti ve öğrenim gördükleri dönem değişkenlerinin farklılık yaratıp yaratmadığı incelenmiştir. $\mathrm{Bu}$ inceleme çok değişkenli varyans analizi (MANOVA) ile gerçekleştirilmiştir. Analiz sonuçları Tablo 3 'te verilmiştir (Tablo 3).

Tablo 3 incelendiğinde bilişsel esneklik düzeyi, öğrenme yaklaşımı, kullanılan öğrenme stratejisi üzerinde farklılık yaratacağı düşünülen temel etkilerden yalnızca cinsiyetin anlamlı farklılık yarattığ $\quad(F(7-608)=7,96, \quad p<.05, \quad p=0,0001)$ belirlenmiştir. Anlamlı farklılık Cohen'in (39) sınıflamasına göre orta etki büyüklüğünde $(\eta 2=0,08)$ belirlenmiştir. Temel etki olarak dönem ve cinsiyet dönem etkileşiminin anlamlı farklılık yaratmadığ1 $(\mathrm{p}>.05, \mathrm{p}=0,177$ ve $\mathrm{p}=0,538$ ) belirlenmiştir. Temel etkilerden cinsiyetin hangi ölçek ve alt ölçeklerden elde edilen toplam puanlarda farklılık yarattığ incelenmiştir. Sonuçlar tablo 4'te verilmiştir (Tablo 4).

Tablo 4 incelendiğinde cinsiyetin yüzeysel öğrenme yaklaşımı üzerinde anlamlı farklılık yarattığ1 $\quad(\mathrm{F}=22,97, \quad \mathrm{p}<.05, \quad \mathrm{p}=0,0001)$ belirlenmiştir. Anlamlı farklılık küçük etki büyüklügünde $(\eta 2=0,04)$ belirlenmiştir. $\mathrm{Bu}$ farklılık erkek öğrenciler lehinedir. Erkek öğrencilerin ortalaması $(\overline{\mathrm{x}}=30,98)$ kadın öğrencilerin ortalamasından $\quad(\overline{\mathrm{x}}=28,05)$ yüksektir. Erkek öğrenciler yüzeysel öğrenmeyi daha çok tercih etmektedir. Cinsiyet dikkat öğrenme stratejisi üzerinde anlamlı farklılık yaratmıştır $(\mathrm{F}=12,88, \mathrm{p}<.05, \mathrm{p}=0,0001)$. Anlaml 1 farklılık küçük etki büyüklüğünde $(\eta 2=0,02)$ belirlenmiştir. $\mathrm{Bu}$ farklılığın kadın öğrenciler lehinedir. Kadın öğrencilerin ortalaması $(\overline{\mathrm{x}}=15)$ erkek öğrencilerin ortalamasından ( $\overline{\mathrm{x}}=14,03)$ yüksektir. Kadın öğrenciler dikkat stratejilerini daha çok kullanmaktadır.
Ders D1ş1 Kitaplar Okuma, Anne Eğitim Düzeyi, Baba Eğitim Düzeyi, Bilişsel Esneklik, Öğrenme Yaklaşımı ve Öğrenme Stratejisi

Araştırmada öğrencilerin bilişsel esneklik düzeyi, öğrenme yaklaşımı ve kullandıkları öğrenme stratejisi üzerinde öğrencilerin ders dişında kitap okuma düzeyleri, anne ve babalarının eğitim düzeyi değişkenlerinin farklılık yaratıp yaratmadığı incelenmiştir. $\mathrm{Bu}$ inceleme çok değişkenli varyans analizi (MANOVA) ile gerçekleştirilmiştir. Analiz sonuçları tablo 5'te verilmiştir (Tablo 5).

Tablo 5 incelendiğinde bilişsel esneklik düzeyi, öğrenme yaklaşımı, kullanılan öğrenme stratejisi üzerinde farklılık yaratacağı düşünülen temel etkilerden yalnızca ders dışı kitap okuma düzeyinin anlamlı farklılık yarattığı $(\mathrm{F}(28$ 226) $=1,51, \quad \mathrm{p}<.05, \quad \mathrm{p}=0,043) \quad$ belirlenmiştir. Anlamlı farklılık küçük etki büyüklüğünde $(\eta 2=0,02)$ belirlenmiştir. Bilişsel esneklik düzeyi, öğrenme yaklaşımı, kullanılan öğrenme stratejisi üzerinde farklılık yaratacağı düşünülen temel etkilerden anne ve babanın eğitim düzeyinin anlamlı farklılık yaratmadığ ${ }_{1}(\mathrm{p}>.05$, $\mathrm{p}=0,084$ ve $\mathrm{p}=0,158$ ) belirlenmiştir. Ders diş1 kitap okuma düzeyi ile anne eğitim düzeyi, ders dışı kitap okuma düzeyi ile baba eğitim düzeyi, anne eğitim düzeyi ile baba eğitim düzeyi ve ders dışı kitap okuma düzeyi, anne eğitim düzeyi ile baba eğitim düzeyi etkileşiminin anlamlı farklılık yaratmadığ 1 ( $\mathrm{p}>.05, \mathrm{p}=0,797$, $\mathrm{p}=0,712, p=0,66$ ve $\mathrm{p}=0,861$ ) belirlenmiştir. Temel etkilerden ders dışı kitap okuma düzeyi hangi ölçek ve alt ölçeklerden elde edilen toplam puanlarda farklılık yarattığı incelenmiştir. Sonuçlar tablo 6'da verilmiştir (Tablo 6).

Tablo 6 incelendiğinde ders dışı kitap okuma düzeyinin dikkat öğrenme stratejisi üzerinde anlamlı farklılık yarattığ 1 (F=4,14, $\mathrm{p}<.05$, $\mathrm{p}=0,003$ ) belirlenmiştir. Anlamlı farklılık küçük etki büyüklüğünde $(\eta 2=0,03)$ belirlenmiştir. 
Ders dışı kitap okuma düzeyi ayda 2-5, ayda 1, yılda 6-10, yılda 2-5 ve yılda 1 şeklinde ölçümlenmiştir. Yapılan Bonferroni çoklu karşılaştırma testi sonucunda bu gruplar arasında yalnızca ayda 2-5 ile yılda 1 kitap okuyan öğrencilerin dikkat öğrenme stratejisi kullanımı arasında fark bulunmuştur. Ayda 2-5 ders diş1 kitap okuyanların ortalaması $(\bar{x}=14,92)$ yılda 1 ders dışı kitap okuyanların ortalamasından $(\overline{\mathrm{x}}=13,37)$ yüksektir. Ders dişı kitap okuma düzeyi yüksek olanlar dikkat öğrenme stratejisini daha çok kullanmaktadır.

Bilişsel Esneklik Düzeyi ve Öğrenme Yaklaşımının Kullanılan Öğrenme Stratejisini Yordama Düzeyi

Araştırmada öğrencilerin bilişsel esneklik düzeyi ve öğrenme yaklaşımının kullandıkları öğrenme stratejisinin anlamlı bir yordayıcısı olup olmadiğı incelenmiştir. $\mathrm{Bu}$ inceleme çok değişkenli regresyon analizi ile gerçekleştirilmiştir. $\mathrm{Bu}$ analiz STATA paket programı aracılığı ile gerçekleştirilmiştir. Yapılan çok değişkenli regresyon analizinin model uyumluluğu tablo 7'de verilmiştir (Tablo 7).

Tablo 7'de görüldüğü gibi çıktı/sonuç değişkenleri (sosyoduyuşsal, anlamlandırma, tekrar ve dikkat öğrenme stratejileri) üzerinde açıklayıcı rolleri modellenen üç değişkene (bilişsel esneklik, derin ve yüzeysel öğrenme yaklaşımları) ait model anlamlıdır $(\mathrm{F}=100,25$, $\mathrm{F}=174,70, \quad \mathrm{~F}=40,34, \quad \mathrm{p}<.05, \quad \mathrm{p}=0,0001) . \quad \mathrm{Bu}$ durumda kurulan regresyon modellerinin uygun olduğuna karar verilmiştir. En yüksek açıklayıcılık oranı derin öğrenme yaklaşımına ( $R 2=0,53$, \%53), daha sonra bilişsel esneklik düzeyine ( $\mathrm{R} 2=0,39, \% 39)$ ve son olarak yüzeysel öğrenme yaklaşımına (R2=0,21, \%21) aittir. Regresyon eşitliğinde yapılan tahminlemeler tablo 8'de verilmiştir (Tablo 8).
Tablo 8'de bilişsel esnekliğin kullanılan öğrenme stratejilerini yordaması eşitliğinde; bilişsel esneklik düzeyinin sosyoduyuşsal öğrenme stratejisinin anlamlı bir yordayıcısı $(p<.05, p=0,0001)$ olduğu belirlenmiştir. Bilişsel esneklik düzeyi yükseldikçe sosyoduyuşsal öğrenme stratejisinin kullanımının da arttığı belirlenmiştir.

Derin öğrenme yaklaşımının kullanılan öğrenme stratejilerini yordaması eşitliğinde; derin öğrenme yaklaşımının sosyoduyuşsal öğrenme stratejisinin $(\mathrm{p}<.05, \mathrm{p}=0,0001)$, anlamlandirma öğrenme stratejisinin $(p<.05, p=0.0001)$, tekrar öğrenme stratejisinin $(\mathrm{p}<.05, \mathrm{p}=0,026)$ anlamlı yordayısı olduğu, dikkat öğrenme stratejisinin ( $>$ >05, p=0,149) anlamlı yordayıcısı olmadı̆̆1 belirlenmiştir. Derin öğrenme yaklaşımı arttıkça sosyoduyuşsal, anlamlandırma ve tekrar stratejisi artmaktadir.

Yüzeysel öğrenme yaklaşımının kullanılan öğrenme stratejilerini yordaması eşitliğinde; yüzeysel öğrenme yaklaşımının sosyoduyuşsal öğrenme stratejisinin $(p<.05, \quad p=0,000)$, anlamlandırma öğrenme stratejisinin $(p<.05$, $\mathrm{p}=0.0001)$, tekrar öğrenme stratejisinin $(\mathrm{p}<.05$, $\mathrm{p}=0,0001)$, dikkat öğrenme stratejisinin $(\mathrm{p}>.05, \mathrm{p}=0,002)$ anlamlı yordayısı olduğu belirlenmiştir. Yüzeysel öğrenme yaklaşımı arttıkça sosyoduyuşsal ve tekrar öğrenme stratejileri artmakta; yüzeysel öğrenme yaklaşımı arttıkça anlamlandırma ve tekrar öğrenme stratejisi kullanımı azalmaktadır.

\section{b. Öğrencilerin Öğrenme, Öğretme ve Sinavlara Yönelik Görüşleri}

Araştırmada öğrencilerin öğrenme, öğretme ortamı, uygulanan sınavlara ilişkin görüşleri odak grup görüşmesi ile elde edilmeye çalışılmıştır. $\mathrm{Bu}$ görüşmelerle öğrencilerin anlamlandırmaları düzeyinde öğrenmeye ilişkin ne tür mesajlar aldıkları ortaya çıkarılmaya 
çalışılmıştır. Her dönemden 2 öğrenci olmak üzere toplamda 12 öğrenci ile gerçekleştirilen odak grup görüşmesi içerik analizi ile çözümlenmiştir. İçerik analizinden üç temaya ulaşılmıştır. Bunlar; "Sınavlar Ne Ölçer?”, "Başarı Ölçütleri”, "Sınavlar ve Eğitimin Örtük Mesajı"dır. $\mathrm{Bu}$ temalar ve temaların altında oluşan kodlar aşağıda verilmiştir.

\section{Sınavlar Ne Ölçer?}

Öğrencilerin anlatımlarının önemli bir kısmının sınavların ne ölçtüğü ile ilgili olduğu belirlenmiştir. Okullarda uygulanan resmi bir eğitim programı olmasına karşın, öğretmenlerin sınıfta uyguladıkları programın ve öğrencilerin önemli gördükleri öğrenmelerin sinavlardan etkilendiği görülmektedir. $\mathrm{Bu}$ araştırmada öğrencilerin sınavların ne ölçtügü ile ilgili görüşleri Şekil 1'de özetlenmiştir (Şekil 1).

Öğrenciler sınavların; öğrenmeleri ölçmediği, öğrencileri daima ezber bilgilere yönlendirdiği, olgu temelli, akıl yürütmeye dayalı sorulardan oluşmadığı, bilgi ve becerilerin gelişimini desteklemediğini belirtmiştir. Örneğin odak görüşme esnasında dönem I'den bir öğrenci ile dönem VI'dan bir öğrenci arasında şu diyalog geçmiştir:

(Dönem I'den bir öğrenci anlatıyor) sınava o kadar çalıştım ki, neredeyse her şeyi derinlemesine öğrenmeye çalıştım. Hocamız "ATP" ile ilgili bir şey sordu. Verdiğim o kadar yoğun cevaba karşın yanlış yanıtlamışım. Meğer hoca hücredeki işlem sırasında ortaya çıkan ve halen hatırlayamadığım \%30'luk bir şeyi yazmamı istiyormuş. Ben şok oldum. (Dönem VI'dan öğrenci araya girerek) yapma ya o hoca hala aynı şeyi mi soruyor. Hoca yıllardır hiç değiştirmemiş kendisini desene!

\section{Başarı Ölçütleri}

Bir hekim olma yolunda neleri öğrenip, hangi bilgi ve becerilere sahip olunduğunda başarılı kabul edilebilirsiniz? Sınavlar ve sınavlar aracılığı ile öğretim üyeleri başarılı olmanın ölçütü konusunda hangi mesajları vermektedir? Araştırmada öğrencilerin başarı ölçütlerine ilişkin anlamlandırmaları Şekil 2'de özetlenmiştir (Şekil 2).

Öğrencilere göre stajlarda başarılı olmak istiyorsanız; staja düzenli gelmeli, katılım göstermeli, saygılı davranmalı, belirsiz başarım ölçütlerine, standart olmayan sınavlara alışmalı, şans faktörünü kabullenmelisiniz. Klinik öncesi dönemde de önceki yılların sorularına iyi çalışmalı, derste kullanılan slaytları ve içindeki bilgileri iyi ezberlemelisiniz. Ancak bu durum sorun olmasa gerek! Öğrenciler lise eğitiminden bu yana ezberlemeye, adil olmayan sinav sistemlerine standartların olmamasına alışıktır. Oysa sınavlar daha adil olabilir, sorular vakalar üzerinden sorulabilir, sınavlar ve eğitim daha çok hasta, vaka ve olgu temelli olabilir. Örneğin, bir öğrenci aşağıda aktarılan sözleri ile yaşadığ duruma bir anlam verememektedir:

Bazı stajlara, "bilemiyorum hoca s1kıntısından midir?", devlet hastanesinden hocalar geliyor. O hocaların stajları çok daha verimli. Hoca stajda, semptomlar, olgular ve yapılmas1 gerekenler, kısaca her şeyi en temelden alıp, son aşamasına kadar o kadar güzel anlatıyor ki. Benim en çok merak ettiğim neden bizim hocalarımız devlet hastanesinden gelen hocalar gibi olamiyorlar. Onların sözlü sınavları da çok daha akılcı ve verimli geçiyor.

Staj döneminde yaşadığı bir anısını paylaşan bir öğrenci, sınavlardaki adaletsiz durumu çok güzel özetlemektedir:

Stajların birinde hocamız bizi seminer odası gibi bir yere aldı. Oturum sıramızı kendisi 
belirledi. Ben masanın başında birinci sırada yer aldım. Benden sonra arkadaşlarım yanıma ikinci, üçüncü vb. sıra ile oturdular. Burada ilginç olan şuydu; ben ilk sırada olduğum için en genel soru bana geliyordu. Ben soruları çok kolay yanıtladim. Ancak ben tam soruya cevap verirken benim cevabım içindeki bir sözcükten hocamız beni durduruyor ve bu ayrintıyı hemen yanımda ikinci sıradaki arkadaşıma soruyordu. İkinci cevap verirken onun cevabının içinde geçen bir kavramdan daha ayrıntı bir bilgiyi üçüncü kişiye soruyordu. Yani anlayacağınız sırayla benden sonraki arkadaşlarıma her defasında daha ayrıntı soru geliyordu. Onlara gelen soruları duydukça ben ecel terleri döküyordum. Bana sorulsa kesinlikle yanıt veremezdim. Ben çok kolay sorulara muhatap olarak kolaylıkla geçtim. Ancak arkadaşlarım çok zorlandı hatta geçemeyenler oldu. Bence çok büyük bir adaletsizlikti.

\section{Sınavlar ve Eğitimin Örtük Mesajı}

Eğitimde her davranış resmi eğitim programı aracılığı ile kazanılmaz. Arka planda işleyen örtük program vardır. Bazen örtük program resmi programdan daha etkili olabilmektedir. Ancak örtük program ve verdiği mesajları algılayabilmek ve anlamlandırabilmek zor olabilmektedir. Araştırmada öğrencilerin sınavlar ve eğitimin örtük mesajlarına ilişkin anlamlandırmaları Şekil 3'te özetlenmiştir (Şekil 3).

Öğrencilere göre sınavlar ve aldıkları eğitim onlara şu mesajları vermiştir: "Nasıl olsa geçeriz!”, ezber önemli, önceki yıllarda sorulan sorular önemli, yine onlar sorulur, öğretim üyesinin beklentisini çöz ve ona göre pozisyon al, derin öğrenmeye çalıştıkça başarısız olursun. Öğrenci olarak bizlerin de eleştirilmesi gerekmez mi? "Evet, eğitime katılımımız düşük!” Bir öğrenci yaşadığı çelişkiyi aşağıdaki biçimde özetliyor. Durumun bilinmezliğini çözdükten sonra kendince başarıyı elde etmiştir:

Ben ilk geldiğim yıllarda kitaplardan ve çeşitli kaynaklardan çok detaylı öğrenmeye çalıştım. Böyle yaptıkça hep not ortalamam daha düşük oldu. Hatta bir dersten bütünlemeye kaldım. Sonra bir karar verdim, slâytlarda yazanları en ince ayrıntısına kadar ezberleme kararı aldım. Şu anda çok daha başarılıyım, not ortalamam daha yüksek ve çok daha kolay ders geçiyorum.

\section{SONUÇ, TARTIŞMA VE ÖNERİLER}

$\mathrm{Bu}$ bölümdeki çıkarımlar ile tartışmalar öncesinde verilerin yalnızca Türkiye'deki bir üniversitenin tıp fakültesi öğrencileri üzerinden elde edildiğinin hatırlatılması yararlı olacaktır. $\mathrm{Bu}$ araştırmanın bir sınırlılığıdır ve yapılan çıkarımların genellenebilirliğini düşürmektedir. Araştırma sonucunda öğrencilerin bilişsel esneklik düzeyinin yüksek olduğu belirlenmiştir. Öğrencilerin derin ve yüzeysel öğrenme yaklaşımına sahip olmakla birlikte, derin öğrenme yaklaşımı düzeylerinin yüzeysel öğrenme yaklaşımı düzeyinden bir miktar yüksek olduğu saptanmıştır. Öğrenciler sosyoduyuşsal, anlamlandırma, tekrar ve dikkat öğrenme stratejilerinin her birinden yararlanmaktadır. Araştırmada öğrencilerin derin öğrenme yaklaşımı ile yüzeysel öğrenme yaklaşımını bir arada yüksek miktarda kullanıldığı yönünde bir sonuca ulaşılmıştır. Bu sonuç bir çelişki gibi görünse de odak grup görüşmeleri göstermiştir ki; eğitim sistemi öğrencilere bazı mesajlar vermektedir. $\mathrm{Bu}$ mesajlardan birisi; “Öğrendiğini derin öğrenmeye çalışırsan sınıfı geçebileceğin garanti değil, ancak gereken bilgileri ezberlersen durum net: Başarı!".

Tıp eğitimi; mesleki bilgi ve klinik beceri, eleştirel düşünme, problem çözme ve karar verme, bilgiyi belirsiz durumlarda yeniden 
yapılandirarak kullanabilme becerilerini kazandırma hedefleri ile derin öğrenme yaklaşımı için öğrencileri yönlendirirken, öğrenilecek içeriğin yoğun, zamanın sınırlı olması ve çok daha önemlisi ölçme ve değerlendirme sisteminin öğrencilerden beklentisi ile tıp öğrencilerini yüzeysel öğrenme yaklaşımına yönlendirebilir (40).

Araştırmada öğrenme yaklaşımları, öğrencinin kişisel özelliklerinin yanı sıra öğrencinin öğrenme ortamına oluşturduğu bir cevap olarak değerlendirilmiştir. Öğrencilerin stratejik bir yaklaşımla, öğrenme kazanımları, içerik, eğitim yöntemleri, öğrenme öğretme ortamı ve ölçme süreçlerinin yönlendirmesi ile derin ve yüzeysel öğrenme yaklaşımlarını durumsal ve değiştirerek kullandıklarını gösterilmektedir (41, 42, 43). Literatürde olduğu gibi bu araştırmada da tıp öğrencilerinin diğer öğrenciler gibi hem derin öğrenme hem de yüzeysel öğrenme stratejilerini bir arada kullanmaktadır.

Araştırmaya katılan öğrencilerin bilişsel esneklik düzeyleri yüksek olarak belirlenmiştir. $\mathrm{Bu}$ durum, öğrencilerin, öğrenme bağlamını ve bununla ilişkili olarak değerlendirme süreçlerini nasıl algıladıklarına bağlı olarak kolaylıkla yüzeysel veya derin öğrenme yaklaşımı arasında geçiş yapmalarını ve her iki öğrenme yaklaşımına da benzer bir şekilde yönelmelerini açıklayabilir.

Öğrenme yaklaşımı öğrenci ile öğrenme görevi arasındaki bir etkileşimdir ve bu etkileşimde ölçme ve değerlendirmenin önemli bir yeri vardır. Ölçme ve değerlendirme öğrenmeyi biçimlendirme konusunda güçlü bir etkiye sahiptir (44, 45, 46). Literatürde geleneksel değerlendirme sisteminin, öğrenmeyi geliştirme ve öğrenmenin bir parçası olması yerine daha çok başarı ve başarısızlık konusunda karar verme süreci olarak görüldüğü belirtilmektedir. Bu türden bir ölçme değerlendirme yaklaşımının yarattığ 1 stres öğrencileri derin öğrenme yerine yüzeysel öğrenmeye yöneltmektedir (47).

Araştırmaya katılan öğrenciler sınavların, öğrenmeleri ölçmediğini, öğrencileri ezber bilgilere yönlendirdiğini belirtmiştir. Bilişsel esnekliğin, kişinin değişen ortam koşullarına göre algısını değiştirebilme yeteneği olduğu ve hedefe yönelik davranışın altında yatan yürütücü işlevleri açıkladığ 1 düşünüldüğünde (8), öğrencilerin öğrenme ve sinav deneyimlerine göre öğrenme yaklaşımları açısından kendilerini yeniden konumlandırmalarını açıklamaktadır. Yapılmış olan çalışmalar, derin ve yüzeysel öğrenme yaklaşımları açısından kadın ve erkekler arasında fark olup olmadığ 1 konusunda farkl11ıklar göstermiştir. Derin ve yüzeysel öğrenme yaklaşımını tercih etme ve yoğun biçimde kullanma konusunda cinsiyetin farklılık yaratmadığını gösteren araştırmalar olduğu gibi $(40,48,54,55)$, erkek öğrencilerin kız öğrencilere göre yüzeysel öğrenme yaklaşımını daha fazla kullandıklarını gösteren $(49,24,53)$, erkek öğrencilerin derin öğrenme yaklaşımı kız öğrencilere göre önemli ölçüde daha fazla tercih ettiğini gösteren $(51,45,52)$ ve k1z öğrencilerin erkek öğrencilerden daha fazla stratejik öğrenme yaklaşımlarını tercih ettiklerini (24) gösteren araştırmalar belirlenmiştir. Bu araştırmada erkek öğrencilerin yüzeysel öğrenme eğilimlerinin kadınlardan yüksek olduğu belirlenmiştir. $\mathrm{Bu}$ sonuç toplumsal cinsiyet farklılıkları, önceki eğitim deneyimleri ve öğrencilerin aldıkları eğitime ve ilgilerine bağlı olarak gelişmiş olabilir.

Kadınlar dikkat öğrenme stratejisini erkeklerden daha çok kullanmaktadır. Ders dışı kitap okuma düzeyi yüksek olanlar dikkat öğrenme stratejisini daha çok kullanmaktadır. Literatürde kız öğrencilerin erkek öğrencilere göre stratejik öğrenme yaklaşımını daha yüksek düzeyde işe koştuklarını, bu nedenle kız öğrencilerin 
çalışmalarında daha yüksek düzeyde başarı odaklı çalıştıklarını gösteren araştırmalar mevcuttur $(49,50)$.

Bilişsel esneklik öğrenme stratejisi kullanmadaki varyansın \%39'unu açıklayan bir değişkendir. Bilişsel esneklik arttıkça sosyoduyuşsal öğrenme stratejisi kullanımı da artmaktadır.

Derin öğrenme yaklaşımı öğrenme stratejisi kullanımındaki varyansın \%53'ünü açıklamaktadır. Derin öğrenme yaklaşımı arttıkça sosyoduyuşsal öğrenme stratejisi, anlamlandırma öğrenme stratejisi ve tekrar öğrenme stratejisi kullanımı artmaktadır.

Yüzeysel öğrenme yaklaşımı öğrenme stratejisi kullanımındaki varyansın \%21'ini açıklamaktadır. Yüzeysel öğrenme yaklaşımı arttıkça sosyoduyuşsal öğrenme stratejisi ve tekrar öğrenme stratejisi kullanımı artmaktadır. Yüzeysel öğrenme yaklaşımı arttıkça anlamlandırma öğrenme stratejisi ve dikkat öğrenme stratejisi kullanımı azalmaktadır. Odak grup görüşmeleri de bu bulguyu desteklemiştir. Sistem ezber, ezberlemek için bol tekrar yönelimlidir. Anlamlandırarak öğrenmek kaçınılmaz bir şekilde derin öğrenme yaklaşımını benimsemeyi gerekli kılacaktır.

Tıp fakültelerinin öğrenme amaç ve hedeflerinin açıkça belirlendiği ve öğrencilerle paylaştığı, işbirliğine dayalı öğrenme, grup çalışmaları, probleme dayalı öğrenme gibi aktif öğrenme yöntemlerini içeren, erken dönemden itibaren klinik ortamlarda uygulamaların yapıldığı eğitim programları geliştirmesi öğrencilerin derin öğrenme yaklaşımlarını seçmelerini destekleyebilir. Ayrıca öğrencilerin değerlendirilmesinde sadece öğrenilen yeni bilgilere değil, öğrenilenleri yapılandırma, dönüştürme, uygulama gibi öğrenme öğretme amaçlarına uygun değerlendirmelere de yer verilmelidir.

$\mathrm{Bu}$ araştırmanın birden çok üniversitede, çok merkezli olarak gerçekleştirilmesi araştırmanın sınırlılığını azaltabilir. Bu nedenle daha geniş katılımlı, çok merkezli bir araştırma planlanması önerilir.

Bilişsel esnekliğin öğrenme ortamına, öğretim üyesi beklentisine, başarım kriterlerine göre öğrencinin tavır almasındaki etkisi daha detaylı incelemeye değer bir konu olarak görülmektedir. $\mathrm{Bu}$ doğrultuda yeni araştırmaların planlanması önerilir.

$\mathrm{Bu}$ araştırmada olduğu gibi farklı üniversitelerin tıp fakültelerinde de öğrenme yaklaşımlarından her birinin durumsal olarak yüksek düzeyde kullanılıp kullanılmadığı, her iki yaklaşımın yüksek düzeyde kullanımı irdelenebilir.

\section{KAYNAKLAR}

1. Martin MM, Anderson CM. The cognitive flexibility scale: Three validity studies. Communication Repots. 1998 Jan; 11:1-9.

2. Dennis JP, Vander Wal JS. The cognitive flexibility inventory: Instrument development and estimates of reliability and validity. Cognitive Therapy and Research [Internet]. 2010 Jun; 34:241-53. Available from: https://link.springer. com/article/10.1007\%2Fs 10608-009-9276-4 DOI: http://dx.doi.org/10.1007/s10608-0099276-4

3. Gülüm İV, Dağ İ. Tekrarlayıcı düşünme ölçeği ve bilişsel esneklik envanterinin Türkçe'ye uyarlanması, geçerliliği ve güvenilirliği. Anadolu Psikiyatri Dergisi. 2012 Jun; 13:21623.

4. Cropley AJ. Creativity and mental health in everyday life. Creativity Research Journal [Internet]. 1990 Nov; 3(3):167-78. Available from: https://www.tandfonline.com/doi/ abs/10.1080/10400419009534351 DOI: http:// 
5. Reiter Palmon R, Mumford MD, Threlfall $\mathrm{KV}$. Solving everyday problems creatively: The role of problem construction and personality type. Creativity Research Journal [Internet]. 1998 Jun; 11(3):187-97. Available from: https://www.tandfonline.com/doi/abs/10.1207/ s15326934crj1103_1 DOI: http://dx.doi. org/10.1207/s15326934crj1103_1

6. Anderson P. Assessment and development of executive function (EF) during childhood. Child Neuropsychology [Internet]. 2002 Jun; 8(2):7182. Available from: https://www.ncbi.nlm.nih. gov/pubmed/12638061 DOI: http://dx.doi. org/10.1076/chin.8.2.71.8724

7. Eslinger PJ, Grattan LM. Frontal lobe and frontal-striatal substrates for different forms of human cognitive flexibility. Neuropsychologia [Internet]. 1993 Jan; 31(1):17-28. Available from: https://www.ncbi.nlm.nih.gov/ pubmed/8437679 DOI: http://dx.doi. org/10.1016/0028-3932(93)90077-D

8. Stevens AD. Social problem-solving and cognitive flexibility: Relations to social skills and problem behavior of at-risk young children. Doctoral Dissertation, Seattle Pacific University. USA; 2009

9. Altunkol F. Üniversite öğrencilerinin bilişsel esneklikleri ile algılanan stres düzeyleri arasındaki ilişkinin incelenmesi. Yüksek Lisans Tezi, Çukurova Üniversitesi, Sosyal Bilimler Enstitüsü, Adana; 2011

10. Bilgin M. Bilişsel esnekliği yordayan bazı değişkenler. Çukurova Üniversitesi Eğitim Fakültesi Dergisi. 2009 Jan; 36(3):142-57.
11. Diril A. Lise öğrencilerinin bilişsel esneklik düzeylerinin sosyodemografik değişkenler ve öfke düzeyi ile öfke ifade tarzları arasındaki ilişki açısından incelenmesi. Yüksek Lisans Tezi, Çukurova Üniversitesi Sosyal Bilimler Enstitüsü, Adana; 2011

12. Gündüz B. Bağlanma stilleri, akılc1 olmayan inançlar ve psikolojik belirtilerin bilişsel esnekliği yordamadaki katkıları. Kuram ve Uygulamada Eğitim Bilimleri [Internet]. 2013 Jun; 13(4), 2071-2085. Available from: http://www.idealonline.com.tr/IdealOnline/ lookAtPublications/paperDetail.xhtml?uId=664 DOI:

http://dx.doi.org/10.12738/

estp.2013.4.170

13. Martin MM, Staggers SM, Anderson CM. The relationships between cognitive flexibility with dogmatism, intellectual flexibility, preference for consistency, and self-compassion. Communication Research Reports [Internet]. $2011 \mathrm{Jul}$; 28(3):275-80. Available from: https:// www.tandfonline.com/doi/full/10.1080/088240 96.2011.587555 DOI: http://dx.doi.org/10.1080 /08824096.2011.587555

14. Lin YW. The effects of cognitive flexibility and openness to change on college students' academic performance. Doctorate Dissertation. La Sierra University; 2013

15. Tchanturia K, Harrison A, Davies $\mathrm{H}$, Roberts M, Oldershaw A, Nakazato M, et al. Cognitive flexibility and clinical severity in eating disorders. Plos One [Internet]. 2011 Jun; 6(6):1-5. Available from: https://journals. plos.org/plosone/article?id=10.1371/journal. pone.0020462 DOI: http://dx.doi.org/10.1371/ journal.pone. 0020462 
16. Merrill, K, Joiner T, Fresco DM, Lewinsohn P. Relationship of Cognitive Flexibility to Depression and Anxiety symptoms in a Large Community Sample of High School Students. A poster presented at the annual meeting of the Association of Behavioral and Cognitive Therapies, Washington, DC. 2005

17. Carlson SM, Moses LJ. Individual differences in inhibitory control and children's theory of mind. Child Development [Internet]. 2001 Jul-Aug; 72:1032-53. Available from: https:// www.ncbi.nlm.nih.gov/pubmed/11480933 DOI: http://dx.doi.org/10.1111/1467-8624.00333

18. Müller U, Zelazo PD, Imrisek S. Executive function and children's understanding of false belief: How specific is the relation? Cognitive Development [Internet]. 2005 Apr-Jun; 20:173-89. Available from: https:// www.sciencedirect.com/science/article/pii/ S0885201404000887?via\%3Dihub DOI: http:// dx.doi.org/10.1016/j.cogdev.2004.12.004

19. Jacques S, Zelazo PD. Language and the development of cognitive flexibility: Implications for theory of mind. In Astington JW, Baird JA editors. Why language matters for theory of mind. Oxford: Oxford University Pres; 2005, pp 144-62

20. Bull R, Scerif G. Executive functioning as a predictor of children's mathematics ability: Inhibition, switching, and working memory. Developmental Neuropsychology [Internet]. 2001 Jun; 19:273-93. Available from: https:// www.tandfonline.com/doi/abs/10.1207/ S15326942DN1903_3 DOI: http://dx.doi. org/10.1207/S15326942DN1903_3

21. Beattie V, Collins B, Mcinnes B
Deep and surface learning: A simple or simplistic dichotomy? Accounting Education [Internet]. 1997 Oct; 6(1):1-12. Available from: https:/www.tandfonline.com/doi/ abs/10.1080/096392897331587 DOI: http:// dx.doi.org/10.1080/096392897331587

22. Batı AH, Tetik C, Gürpınar E. Öğrenme yaklaşımları ölçeği yeni şeklini Türkçeye uyarlama ve geçerlilik güvenirlilik çalışması. Türkiye Klinikleri J. Med. Sci. 2010 Oct; 30(5):1639-46.

23. Gordon C, Debus R. Developing deep learning approaches and personal teaching efficacy within a preservice teacher education context. Br J Educ Psychol [Internet]. 2002 Dec; 72(4):483-511. Available from: https:/www. ncbi.nlm.nih.gov/pubmed/12495563 DOI: http://dx.doi.org/10.1348/00070990260377488

24. Biggs JB. Student approaches to learning and studying. Melbourne: Australian Council for Educational Research; 1987

25. Açıkgöz KÜ. Etkili öğrenme ve öğretme. İzmir: Biliş; 2009

26. Weinstein CE, Mayer RE. The teaching of learning strategies. In Wittrock $M$, editor. Handbook of research on teaching. New York, NY: Macmillan; 1986, pp. 315-327

27. Arends RI. Classroom instruction and management. New York: The McGraw-Hill; 1997

28. Ashman A, Conway R. An introduction to cognitive education: Theory and applications. The UK: Routledge; 2002 
29. Özer B. İlköğretim ve ortaöğretim okullarının eğitim programlarında öğrenme stratejileri. Eğitim Bilimleri ve Uygulama. 2002 Jun; 1(1):17-32.

30. Çelikkaya T. Sosyal bilgiler öğretmen adaylarının kullandıkları öğrenme stratejileri. Ahi Evran Üniversitesi, Eğitim Fakültesi Dergisi. 2010 Ara; 11(3):65-84

31. Özdamar K. Paket programlar ile istatistiksel veri analizi. Eskişehir: Nisan Kitabevi; 2013

32. Büyüköztürk Ş. Sosyal bilimler için veri analizi el kitabı. Ankara: Pegem Akademi; 2013

33. Kalaycı Ş. SPSS uygulamalı çok değişkenli istatistik teknikleri. Ankara: Asil Yayın Dağıtım; 2005

34. Green SB, Salkind NJ. Using SPSS for windows and Macintosh-analyzing and understanding data. USA: Pearson Prentice Hal; 2008

35. Tabachnick BG, Fidell LS. Using multivariate statistics. The USA: Pearson Education; 2013

36. Pallant J. SPSS survival manual. The USA: McGraw-Hill Education; 2016

37. Everitt BS, Howell DC. Encyclopedia of statistics in behavioral science. The UK: John Willey and Sons; 2005

38. Field A. Discovering statistics using IBM SPSS Statistics. The USA: Sage; 2018

39. Cohen J. Statistical power analysis fort he behavioral science. The USA: Lawrence
Erlbaum Associates Publishers; 1988

40. Chonkar SP, Ha TC, Hang Chu SS, Ng AX, Shan Lim ML, Ee TX, et al. The predominant learning approaches of medical students. BMC Medical Education [Internet]. 2018 Jan; 18(17):2-8. Available from: https://bmcmededuc.biomedcentral.com/ articles/10.1186/s12909-018-1122-5 DOI: http://dx.doi.org/10.1186/s12909-018-1122-5

41. Delgado ÁHA, Almeida JPR, Mendes LSB, Oliveira IN, Ezequiel ODS, Lucchetti ALG, et al. Are surface and deep learning approaches associated with study patterns and choices among medical students? A cross-sectional study. Sao Paulo Medical Journal [Internet]. 2018 Sep-Oct; 136(5):414-20. Available from: http://www.scielo.br/scielo.php?script=sci arttext\&pid=S1516-31802018000500414 DOI: $\quad$ http://dx.doi.org/10.1590/15163180.2018 .0200060818

42. Hall E. The tenacity of learning styles: a response to Lodge, Hansen, and Cottrell. Learning: Research and Practice [Internet]. 2016 Jan; 2:18-26. Available from: https://www. tandfonline.com/doi/abs/10.1080/23735082.20 16.1139856 DOI: http://dx.doi.org/10.1080/237 35082.2016.1139856

43. Nijhuis JFH, Sergers MSR, Gijselaers WH. Influence of redesigning a learning environment on student perceptions and learning strategies. Learning Environments Research [Internet]. 2005 Jan; 8:67-93. Available from: https:// eric.ed.gov/?id=EJ924373 DOI: http://dx.doi. org/10.1007/s10984-005-7950-3

44. Michael P, Keith T. Understanding Learning and Teaching. The experience in Higher 
Education. Open Univeristy Press; 1999

45. Severiens S, Ten Dam G. Gender and gender identitydifferencesinlearningstyles. Educational Psychology [Internet]. 1997 Nov; 17:79-93. Available from: https:/www.tandfonline.com/ doi/abs/10.1080/0144341970170105 DOI: http://dx.doi.org/10.1080/0144341970170105

46. Wilson K, Grif JF. Assessing the impact of learning environments on students' approaches to learning: Comparing conventional and action learning designs. Assessment \& Evaluation in Higher Education [Internet]. 2005 Sep; 30(1):87-101. Available from: https://www.tandfonline.com/doi/full/10.108 0/0260293042003251770 DOI: http://dx.doi. org/10.1080/0260293042003251770

\section{Birenbaum M, Breuer K, Cascallar E, Dochy} F, Dori Y, Ridgway J, et al. A learning integrated assessment system, In Wiesemes R. Nickmans G. editors. European association for research on learning and instruction. EARLI Series of Position Papers [Internet]. Available from: https://community.dur.ac.uk/smart.centre1/ publications/EARLI\%20Position\%20paper\%20 1\%20assessment.pdf; 2005, pp 1-8

48. Wickramasinghe DP, Samarasekera DN. Factors influencing the approaches to studying of preclinical and clinical students and postgraduate trainees. BMC Medical Education [Internet]. 2011 May, 11:22. Available from: https://www. ncbi.nlm.nih.gov/pubmed/21599886 DOI: http://dx.doi.org/10.1186/1472-6920-11-22

49. Ekinci N. Üniversite öğrencilerinin öğrenme yaklaşımlarının belirlenmesi ve öğretmeöğrenme süreci değişkenleri ile ilişkileri. Doktora Tezi, Hacettepe Üniversitesi, Sosyal Bilimler Enstitüsü, Ankara; 2008

50. Smith SN, Miller RJ. Learning approaches:
Examination type, discipline of study, and gender. Educational Psychology [Internet]. 2005 Oct; 25(1):43-53. Available from: https://www.tandfonline.com/doi/full/10.108 0/0144341042000294886 DOI: http://dx.doi. org/10.1080/0144341042000294886

51. Miller CD, Finley J, McKinley DL. Learning approaches and motives: Male and female differences and implications for learning assistance programs. Journal of College Student Development. 1990 May; 31(2):147-54.

52. Watkins $D$. The influence of social desirability on learning process questionnaires: A neglected possibility? Educational Psychology. 1996 Jun; 52:260-263.

53. Mpofu E, Oakland T. Predicting school achievement in zimbabwean multiracial schools using biggs' learning process questionnaire. South African Journal of Psychology [Internet]. 2001 Aug; 31(3):20-9. Available from: https://journals.sagepub.com/doi/ abs/10.1177/008124630103100303 DOI: http:// dx.doi.org/10.1177/008124630103100303

54. RichardsonJTE, King E. Genderdifferencesin the experience of higher education: Quantitative and qualitative approaches. Educational Psychology [Internet]. 1991 Nov; 11:363-382. Available from: https://www.tandfonline.com/ doi/abs/10.1080/0144341910110311 Doi: http:// dx.doi.org/10.1080/0144341910110311

55. Watkins D, Mboya M. Assessing the learning processes of Black South African students. The Journal of Psychology [Internet]. 1997 Apr; 131(6):636-640. Available from: https://www.tandfonline.com/doi/ abs/10.1080/00223989709603845 Doi: http:// dx.doi.org/10.1080/00223989709603845 
Tablo 1. Araştırma Grubunda Yer Alan Öğrencilerin Sahip Olduğu Bazı Özellikler

\begin{tabular}{|c|c|c|c|}
\hline \multicolumn{2}{|c|}{ Değișken } & Frekans & Yüzde \\
\hline \multirow{2}{*}{ Cinsiyet } & Erkek & 299 & 47,8 \\
\hline & Kadın & 327 & 52.2 \\
\hline \multirow{6}{*}{ Dönem } & Dönem I & 122 & 19,5 \\
\hline & Dönem II & 105 & 16,8 \\
\hline & Dönem III & 112 & 17,9 \\
\hline & Dönem IV & 121 & 19,3 \\
\hline & Dönem V & 90 & 14,4 \\
\hline & Dönem VI & 76 & 12,1 \\
\hline \multirow{5}{*}{$\begin{array}{l}\text { Ders Çalışma Amacı Dişında } \\
\text { Tıp ile İlgili Kitap Okuma } \\
\text { Düzeyi }\end{array}$} & Ayda 2-5 & 132 & 21,2 \\
\hline & Ayda bir & 205 & 32,7 \\
\hline & Y1lda 6-10 & 106 & 16,9 \\
\hline & Y1lda 2-5 & 113 & 18,1 \\
\hline & Y1lda bir & 70 & 11,2 \\
\hline & Toplam & 626 & 100 \\
\hline
\end{tabular}

Tablo 2. Tıp Fakültesi Öğrencilerinin Bilişsel Esneklik Düzeyleri, Tercih Ettikleri Öğrenme Yaklaşımları ve Kullandıkları Öğrenme Stratejileri

\begin{tabular}{|l|l|c|c|c|c|c|c|c|}
\hline & \multicolumn{1}{|c|}{ Değişken } & $\mathrm{N}$ & $\bar{X}$ & Std. Sapma & Mod & Medyan & $\begin{array}{c}\text { Mini } \\
\text { mum }\end{array}$ & $\begin{array}{c}\text { Maksim } \\
\text { um }\end{array}$ \\
\hline \multirow{2}{*}{ Bilişsel Esneklik } & $\begin{array}{l}\text { Bilişsel } \\
\text { Esneklik }\end{array}$ & 626 & $45,94 \pm 0,37$ & 9,17 & 48 & 46 & 12 & 72 \\
\hline \multirow{2}{*}{$\begin{array}{l}\text { Öğrenme } \\
\text { Yaklaşımı }\end{array}$} & Derin & 626 & $31,37 \pm 0,31$ & 7,85 & 30 & 31 & 10 & 50 \\
\cline { 2 - 9 } & Yüzeysel & 626 & $29,45 \pm 0,33$ & 8,14 & 30 & 30 & 10 & 50 \\
\hline \multirow{3}{*}{$\begin{array}{l}\text { Öğrenme } \\
\text { Stratejisi }\end{array}$} & $\begin{array}{l}\text { Sosyo- } \\
\text { duygusal }\end{array}$ & 626 & $59,60 \pm 0,46$ & 11,52 & 54 & 58 & 18 & 90 \\
\cline { 2 - 9 } & $\begin{array}{l}\text { Anlamlandırm } \\
\text { a }\end{array}$ & 626 & $43,91 \pm 0,40$ & 10,08 & 39 & 42 & 13 & 65 \\
\cline { 2 - 9 } & Tekrar & 626 & $16,73 \pm 0,15$ & 3,81 & 15 & 16 & 5 & 25 \\
\cline { 2 - 9 } & Dikkat & 626 & $14,54 \pm 0,14$ & 3,57 & 12 & 14 & 4 & 20 \\
\hline
\end{tabular}

N: Kişi Sayısı, $\bar{X}$ : Aritmetik Ortalama, S: Standart Sapma 
Tablo 3. Öğrencilerin cinsiyet ve öğrenim gördüğ̈ü döneme göre bilişsel esneklik düzeyleri, tercih ettikleri öğrenme yaklaşımları ve kullandıklanı öğrenme stratejilerinin karşılaştırılması (Hotelling Trace Test)

\begin{tabular}{|l|c|c|c|c|c|c|}
\hline \multicolumn{1}{|c|}{ Varyansın Kaynağ1 } & Değer & $\mathrm{F}$ & sd (Hipotez) & sd (Hata) & $\mathrm{p}$ & $\eta^{2}$ \\
\hline Kesişim & 34,05 & 2957,83 & 7 & 608 & 0,000 & 0,97 \\
\hline Cinsiyet & 0,09 & 7,96 & 7 & 608 & 0,000 & 0,08 \\
\hline Dönem & 0,07 & 1,22 & 35 & 3032 & 0,177 & 0,01 \\
\hline Cinsiyet* Dönem & 0,06 & 0,96 & 35 & 3032 & 0,538 & 0,01 \\
\hline
\end{tabular}

F: F Testi Değeri, sd: Serbestlik Değeri, p: Önem lilik Düzeyi, $\eta^{2}$ : Eta Etki Büyüklüğü

Tablo 4. Öğrencilerin cinsiyetine göre bilişsel esneklik düzeyleri, tercih ettikleri öğrenme yaklaşımları ve kullandıkları öğrenme stratejilerinin karşılaştırılması

\begin{tabular}{|l|c|c|c|c|c|c|}
\hline Ölçek/Alt Ölçek & Kareler Toplamı & sd & Kareler Ortalamas1 & F & $p$ & $\eta^{2}$ \\
\hline Bilişsel Esneklik Düzeyi & 244,26 & 1 & 244,26 & 2,90 & 0,089 & 0,01 \\
\hline Derin Öğrenme Yaklaşım1 & 81,78 & 1 & 81,78 & 1,32 & 0,251 & 0,00 \\
\hline Yüzeysel Ö̆renme Yaklaşımı & 1473,06 & 1 & 1473,06 & 22,97 & 0,000 & 0,04 \\
\hline Sosyo-duyuşsal Öğrenme Stratejisi & 186,31 & 1 & 186,31 & 1,39 & 0,238 & 0,00 \\
\hline Anlamlandırma Ŏgrenme Stratejisi & 178,61 & 1 & 178,61 & 1,75 & 0,186 & 0,00 \\
\hline Tekrar Öğrenme Stratejisi & 0,38 & 1 & 0,38 & 0,03 & 0,872 & 0,00 \\
\hline Dikkat Öğrenme Stratejisi & 160,19 & 1 & 160,19 & 12,88 & 0,000 & 0,02 \\
\hline
\end{tabular}

F: F Testi Değeri, sd: Serbestlik Değeri, p: Önem lilik Düzeyi, $\eta^{2}$ : Eta Etki Büyüklüğü

Tablo 5. Öğrencilerin ders dışı kitap okuma, anne ve baba eğitim düzeyine göre bilişsel esneklik düzeyleri, tercih ettikleri öğrenme yaklaşımları ve kullandıkları öğrenme stratejilerinin karşılaştırılması (Hotelling Trace Test)

\begin{tabular}{|c|c|c|c|c|c|c|}
\hline Varyansin Kaynağı & Değer & $\mathrm{F}$ & $\begin{array}{c}\text { sd } \\
\text { (Hipotez) }\end{array}$ & sd & $\mathrm{p}$ & $\eta^{2}$ \\
\hline Kesişim & 9,24 & 736,65 & 7 & 558 & 0,000 & 0,90 \\
\hline Ders D1ş1 Kitap Okuma & 0,08 & 1,51 & 28 & 2226 & 0,043 & 0,02 \\
\hline Anne Eğitim Düzeyi & 0,05 & 1,38 & 21 & 1670 & 0,115 & 0,02 \\
\hline Baba Eğitim Düzeyi & 0,05 & 1,21 & 21 & 1670 & 0,229 & 0,02 \\
\hline $\begin{array}{l}\text { Ders D1ş1 Kitap Okuma Düzeyi*Anne Eğitim } \\
\text { Düzeyi }\end{array}$ & 0,13 & 0,87 & 84 & 3894 & 0,797 & 0,02 \\
\hline $\begin{array}{l}\text { Ders Diş1 Kitap Okuma Düzeyi*Baba Eğitim } \\
\text { Düzeyi }\end{array}$ & 0,14 & 0,91 & 84 & 3894 & 0,712 & 0,02 \\
\hline Anne Eğitim Düzeyi*Baba Eğitim Düzeyi & 0,12 & 1,32 & 49 & 3894 & 0,066 & 0,02 \\
\hline $\begin{array}{l}\text { Ders Diş1 Kitap Okuma Düzeyi*Anne Eğitim } \\
\text { Düzeyi*Baba Eğitim Düzeyi }\end{array}$ & 0,22 & 0,87 & 140 & 3894 & 0,861 & 0,03 \\
\hline
\end{tabular}

F: F Testi Değeri, sd: Serbestlik Değeri, p: Önem lilik Düzeyi, $\eta^{2}$ : Eta Etki Büyüklüğü 
Tablo 6. Öğrencilerin ders dışı kitap okuma düzeyine göre bilişsel esneklik düzeyleri, tercih ettikleri öğrenme yaklaşımları ve kullandıkları öğrenme stratejilerinin karşılaştırılması

\begin{tabular}{|l|c|c|c|c|c|l|}
\hline Ölçek/Alt Ölçek & Kareler Toplamı & sd & Kareler Ortalaması & F & $p$ & $\eta^{2}$ \\
\hline Bilişsel Esneklik Düzeyi & 454,83 & 4 & 113,71 & 1,35 & 0,252 & 0,01 \\
\hline Derin Ö̆renme Yaklaşımı & 346,52 & 4 & 86,63 & 1,41 & 0,228 & 0,01 \\
\hline Yüzeysel Öğrenme Yaklaşım1 & 220,96 & 4 & 55,24 & 0,85 & 0,496 & 0,01 \\
\hline Sosyo-duyuşsal Ögrenme Stratejisi & 175,98 & 4 & 43,99 & 0,34 & 0,854 & 0,00 \\
\hline Anlamlandırma Öğrenme Stratejisi & 363,21 & 4 & 90,80 & 0,89 & 0,464 & 0,01 \\
\hline Tekrar Öğrenme Stratejisi & 73,27 & 4 & 18,32 & 1,26 & 0,287 & 0,01 \\
\hline Dikkat Öğrenme Stratejisi & 207,98 & 4 & 51,99 & 4,14 & 0,003 & 0,03 \\
\hline
\end{tabular}

F: F Testi Değeri, sd: Serbestlik Değeri, p: Önemlilik Düzeyi, $\eta^{2}$ : Eta Etki Büyüklüğüu

Tablo 7. Regresyon model uyumu

\begin{tabular}{|l|c|c|c|c|}
\hline \multicolumn{1}{|c|}{ Eşitlik } & $\mathrm{N}$ & $\mathrm{R}^{2}$ & $\mathrm{~F}$ & $\mathrm{p}$ \\
\hline Bilişsel Esneklik & 626 & 0,39 & 100,25 & 0,000 \\
\hline Derin Ö̆ğrenme Yaklaşım1 & 626 & 0,53 & 174,70 & 0,000 \\
\hline Yüzeysel Öğrenme Yaklaşım1 & 626 & 0,21 & 40,34 & 0,000 \\
\hline
\end{tabular}

N: Kişi Sayıs1, R²: Regresyon Belirleyicilik Düzeyi, p: Önem lilik Düzeyi, F: Model F Testi

Tablo 8. Öğrencilerin bilişsel esneklik düzeyi ve öğrenme yaklaşımlarının kullandıkları öğrenme stratejilerini yordama düzeyi

\begin{tabular}{|l|l|c|c|c|c|}
\hline \multicolumn{2}{|c|}{} & $\beta$ & Standart Hata & $\mathrm{t}$ & $\mathrm{p}$ \\
\hline \multirow{4}{*}{ Bilişsel Esneklik Düzeyi } & Sabit & 15,66 & 0,03 & 10,11 & 0,000 \\
\cline { 2 - 5 } & Sosyo-duyuşsal Öğrenme Stratejisi & 0,37 & 0,04 & 8,90 & 0,000 \\
\cline { 2 - 5 } & Anlamlandırma Öğrenme Stratejisi & 0,09 & 0,05 & 1,60 & 0,109 \\
\cline { 2 - 5 } & Tekrar Öğrenme Stratejisi & 0,09 & 0,12 & 0,76 & 0,446 \\
\cline { 2 - 5 } & Dikkat Öğrenme Stratejisi & 0,18 & 0,12 & 1,52 & 0,128 \\
\hline \multirow{5}{*}{ Derin Öğrenme Yaklaşımı } & Sabit & 2,13 & 1,17 & 1,83 & 0,068 \\
\cline { 2 - 5 } & Sosyo-duyuşsal Öğrenme Stratejisi & 0,29 & 0,03 & 9,19 & 0,000 \\
\cline { 2 - 5 } & Anlamlandırma Öğrenme Stratejisi & 0,24 & 0,04 & 5,78 & 0,000 \\
\cline { 2 - 5 } & Tekrar Öğrenme Stratejisi & 0,21 & 0,09 & 2,23 & 0,026 \\
\cline { 2 - 5 } & Dikkat Öğrenme Stratejisi & $-0,13$ & 0,09 & $-1,44$ & 0,149 \\
\hline \multirow{5}{*}{ Yüzeysel Öğrenme Yaklaşımı } & Sabit & 13,67 & 1,57 & 8,69 & 0,000 \\
\cline { 2 - 5 } & Sosyo-duyuşsal Öğrenme Stratejisi & 0,36 & 0,04 & 8,48 & 0,000 \\
\cline { 2 - 5 } & Anlamlandırma Öğrenme Stratejisi & $-0,21$ & 0,06 & $-3,85$ & 0,000 \\
\cline { 2 - 5 } & Tekrar Öğrenme Stratejisi & 0,55 & 0,13 & 4,33 & 0,000 \\
\cline { 2 - 5 } & Dikkat Öğrenme Stratejisi & $-0,38$ & 0,12 & $-3,11$ & 0,002 \\
\hline
\end{tabular}

$\beta$ : İlgili Değişkenin Regresyon Katsayısı, t: Değiş̧ken t değeri, p: Önemlilik Düzeyi 


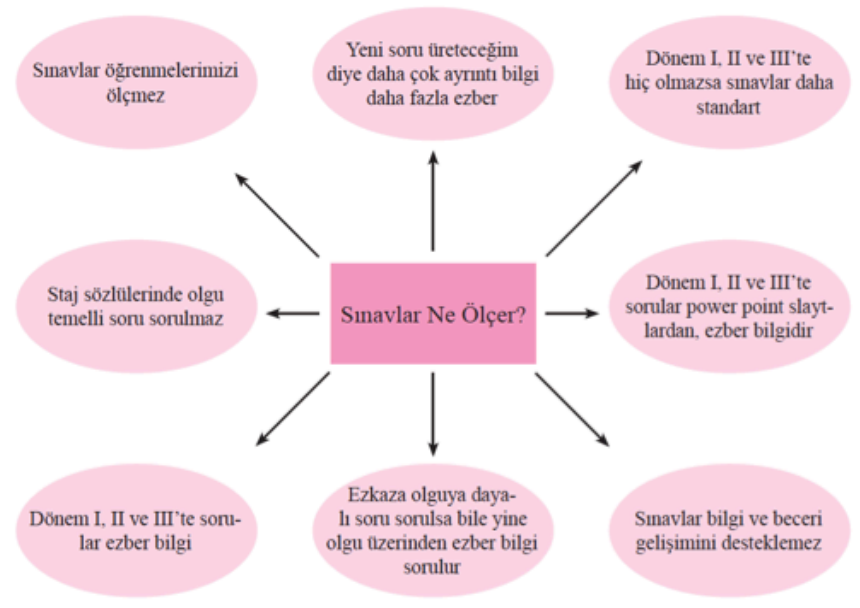

\section{Şekil 1. Sinavlar ne ölçer?}

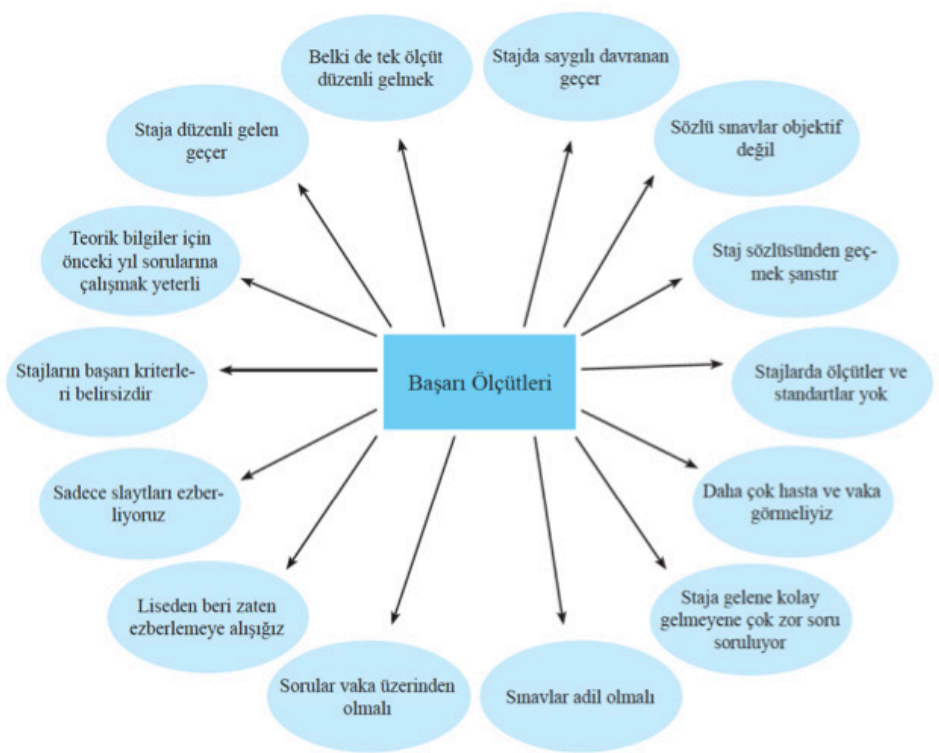

\section{Şekil 2. Başarı ölçütleri}




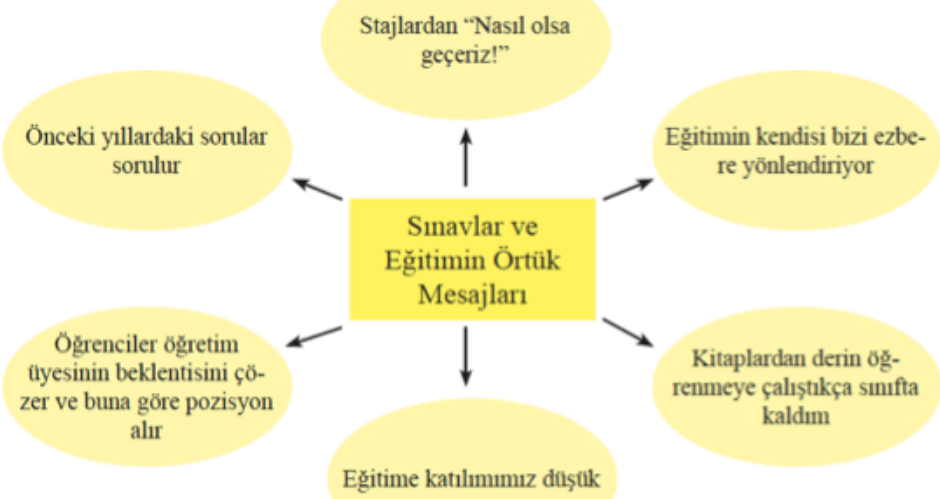

Şekil 3. Sınavlar ve eğitimin örtük mesajları 